\title{
Male and Female Teachers' Opinion towards Digital Literacy Training
}

\author{
Zaiyana Putri' ${ }^{1}$, Marisa Yoestara ${ }^{2 *}$, Munawir $^{3}$ \\ ${ }^{1,2}$ Faculty of Teacher Training and Education, Universitas Serambi Mekkah, Aceh, Indonesia \\ ${ }^{3}$ Faculty of Engineering, Universitas Serambi Mekkah, Aceh, Indonesia \\ *Corresponding Author: marisayoestara@serambimekkah.ac.id
}

\begin{abstract}
This study aims to examine differences between male and female teachers' perception of the digital literacy training. The design of the study was descriptive quantitative study, in which the researchers described differences in both male and female teachers' perception in the digital literacy training conducted in Pidie Jaya. 16 senior high school teachers in SMA Negeri 1 Bandar Baru became the participants of the study. There were 6 male teachers and 10 female teachers. The researchers used the questionnaire that was developed to find out perception in terms of 5 aspects; speakers, participants, materials, atmospheres, and facilities. The data were then analyzed through some steps including grouping the data based on gender and finding the average percentage of each aspect based on gender. The results show that both male and female agreed that the digital literacy training conducted was very effective. A small number of female teachers thought that materials, atmospheres, participants, and facilities were not very effective. For male teachers, only materials and speakers that were claimed to be not very effective, $3 \%$ and $4 \%$ respectively.
\end{abstract}

Keywords: Male and Female Teachers, Perception, Digital Literacy Training

\section{Introduction}

The rapid improvement of Information Communication and Technology (ICT) gives impact towards many sectors of life. The new trend of cyber city, cyber community, and cyber school also become the new issues in today's society. The integration of ICT itself in education is also undeniable since it brings some benefits (Soroya \& Ameen, 2020).Moreover, during the pandemic of COVID-19, almost all aspects of life should be done online, and ICT is seen as a solution including in teaching and learning process. Some researchers agree that ICT integration in education can give benefit for both teachers and students (Ghavifekr \& Rosdy, 2015; Mbugua et al., 2015; Ravinath,2019).

In 2016, Indonesian Government proposed Gerakan Literasi Nasional (GLN) or National Literacy Movement to overcome the literacy and numeracy mastery of Indonesian students. There are six literacy masteries that should be comprehended by Indonesian students (Kemendikbud, 2017). Among these six literacies, digital literacy becomes a trending issue currently. This trend also happens in Aceh, so that is why many institutions ask their employees to have digital literacy competency. However, there are some data showed that there are some differences between males and females in using ICT (Markauskaite, 2006). In line with the previous statement above, Shapka and Ferrari (2003) as cited in Markauskaite(2006, p.2) say that "female teachers tend to be more anxious, less experienced and less confident about their ICT competencies and it is less likely that they will apply computers for various teaching and learning purposes compared with their male colleagues". From this statement, it is obvious that the effectiveness ofICT integration in teaching and learning process depends on teachers' preparedness, teachers' competence and confidence, beliefs, and attitudes in using ICT (Gebhardt et al., 2019). 
Additionally, the rapid growth of the use of ICT in education has risen the issue about the gender differences among teachers' attitude towards ICT. These issues can be caused by several factors, such as culture, norms, and values. On the other hand, in order to improve teachers' competence in ICT mastery, government has required both male and female teachers to join professional development programs, such as training, seminar, and workshop. Furthermore, since it is believed that teachers play a critical role in the implementation process, teachers' attitude towards ICT should be analysed earlier when technology is implemented (Islahi \& Nasrin, 2019).

In accordance with the above statement, some relevant studies have been conducted. According to Makworo et al. (2021), knowing teachers' beliefs based on the gender's perspective towards the ICT integration in education becomes important. Their study found that there was no effect on teachers' attitude in participating in digital literacy based on gender differences. Furthermore, Islahiand Nasrin (2019) also figured out that there are no gender specific differences in attitude towards information technology found. Based on these results, it can be concluded that the effective use of technology in classrooms should be expected from all teachers no matter of their gender. Additionally, having the data about the distribution use of ICT among teachers can give government and stakeholder in understanding and mapping on how to encourage male and female teachers in integrating ICT into teaching and learning process (Manyilizu \& Gilbert, 2015).

Due to the reason mentioned earlier, the writers see that it is important to investigate about male and female teachers' opinion in joining digital literacy training that was held at SMA Negeri 1 Bandar Baru in Pidie Jaya.

\section{Method}

This study used a descriptive quantitative design, in which the researcher analysed the qualitative data (percentage result) and described the findings in detail, particularly to examine differences between male and female's perception of the digital training conducted in SMAN 1 Bandar Baru, Pidie Jaya.

The total participants in this study were 16 teachers; 10 female teachers and 6 male teachers. They were varied in the subject matter they taught, including Biology, Religion, English, and many others. They also varied in their ages ranging from 23 years old to 50 years old

The instrument used in this study was a questionnaire that was specifically designed containing 20 items about teachers' opinion of the digital literacy training in terms of speakers, materials, participants, atmosphere, and facilities. To analyse the data, the researchers used some steps, including grouping the data per aspects per gender and comparing the findings.

\section{Results and Discussions}

\subsection{Male Teachers' Perception of Digital Literacy Training}

The following figure illustrates the perception of male teachers in SMAN 1 Bandar Baru, Pidie Jaya in terms of their perception in the digital literacy training. 


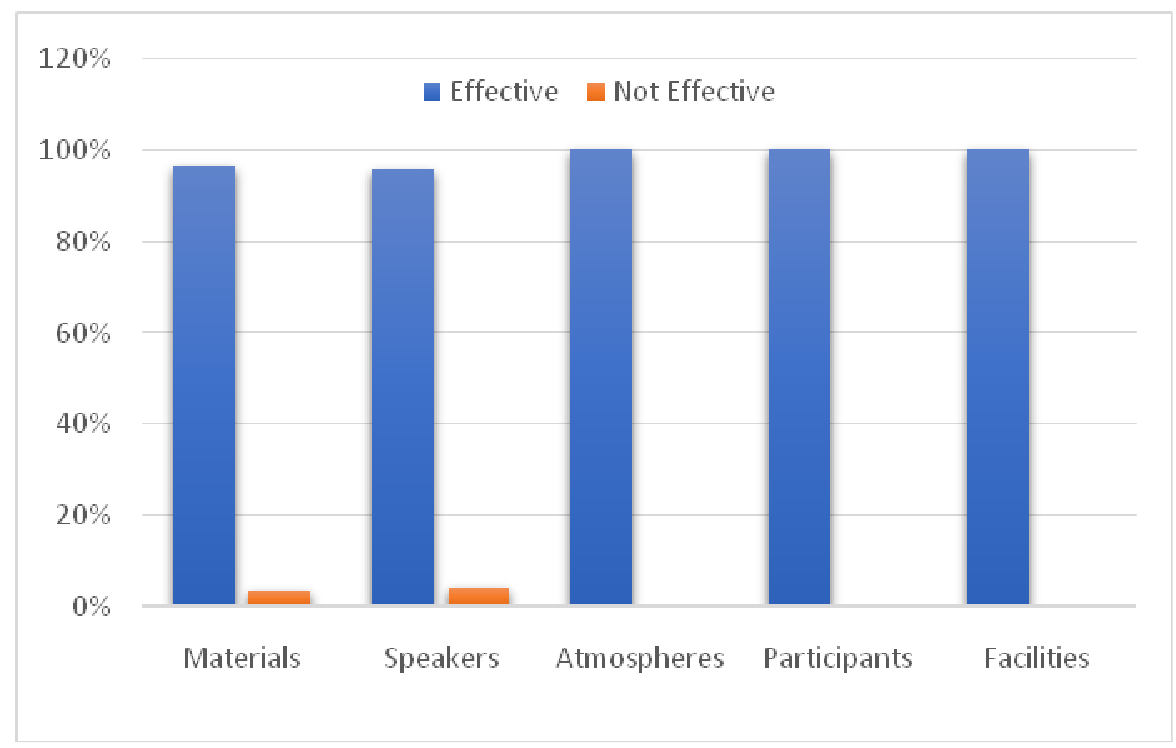

Figure 1. Male's Perception towards Digital Literacy Training

It is clear from the figure that male teachers have positive perception towards the digital literacy training. All male teachers agreed that the atmosphere in the training was very conducive; the participants were also very supportive to each other; and the facilities provided was good to support the digital literacy training. However, they had a slightly varied answer in terms of materials and speakers. There were about $3 \%$ of the male teachers who claimed that the materials were not very effective, while the rest of $97 \%$ think that the materials were effective and clear. Additionally, about $4 \%$ of the male teachers thought that the speakers were not very effective.

\subsection{Female Teachers' Perception of Digital Literacy Training}

This figure describes the female teachers' perception about the effectiveness of the digital literacy training conducted in SMAN 1 Bandar Baru, Pidie Jaya.

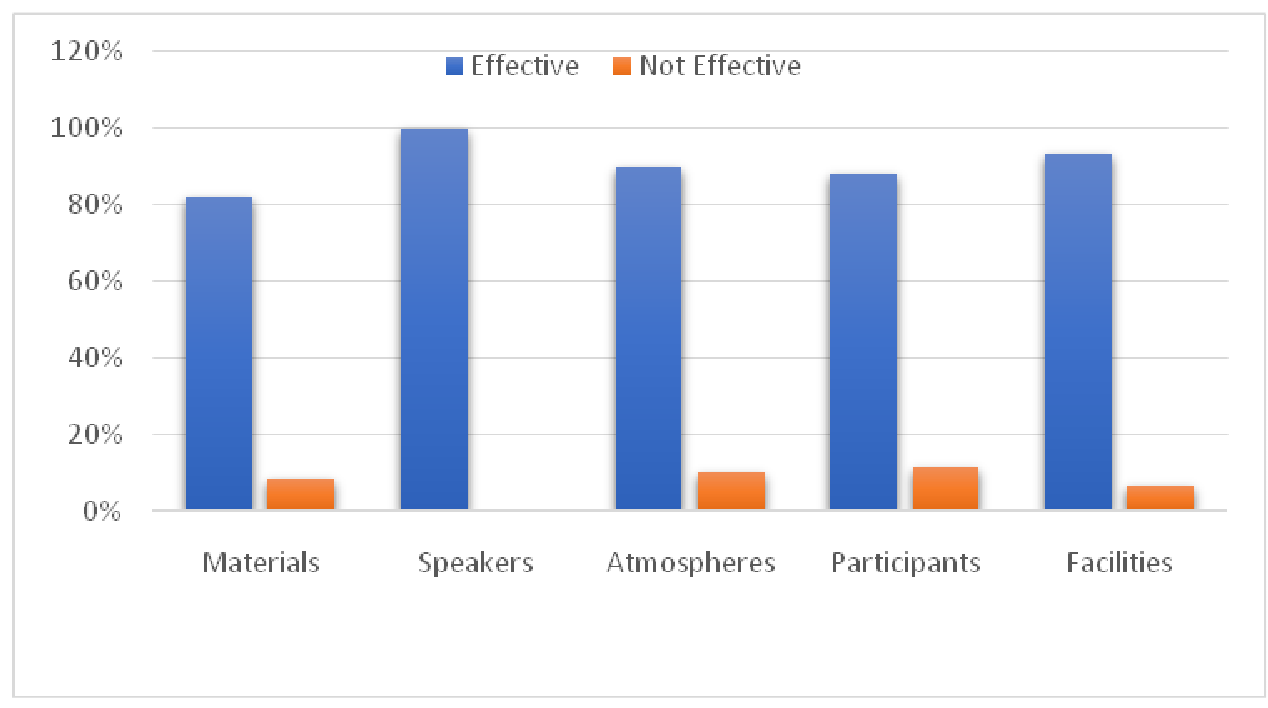

Figure 2. Female's Perception towards Digital Literacy Training 
The above figure illustrates that female teachers had more variation in their perception about the digital literacy training. All of the female teachers agreed that the speakers in the digital literacy training was very good at delivering the training materials. The most varied perception was in the participants as $12 \%$ of the female teachers claimed that the participants were not very supportive in the training. Meanwhile, about $10 \%$ of the teachers believed that the atmosphere was also not very effective. Furthermore, about $8 \%$ and $7 \%$ of them also claimed that the materials provided and the facilities prepared in the training were not very effective.

\subsection{Differences between Male and Female Teachers' Perception of Digital Literacy Training}

From the above two figures, it was obvious that male teachers have more positive perception towards the digital literacy training conducted in SMAN 1 Bandar Baru, Pidie Jaya. There were only a very small number of them claimed that the training was not very effective in terms of materials and speaker, $3 \%$ and $4 \%$ respectively. Meanwhile female teachers seem to have different perception in all aspects, except the speakers of the training. Although the variation was higher compared to male teachers, those female teachers who thought the training was not very effective was still categorized into a small percentage. About $7 \%$ of the female teachers claimed that the facilities were not very supportive; $8 \%$ of them believed that the materials were not effective enough; $10 \%$ claimed the ineffectiveness of the digital literacy training were in the atmospheres aspect; and $12 \%$ of them believed that the participants were not very conducive.

Although male seemed to have more positive opinions towards the digital literacy training, the differences were not very significant between the genders. This finding was similar to the previous study by Islahi and Nasrin (2019), who also found that there were no gender specific differences in the attitude towards the information and technology.

\section{Conclusions}

Overall, this study revealed that there were some differences in male and female teachers' perspective towards digital literacy training that was conducted in Pidie Jaya. Male teachers seemed to have more positive opinions about the training compared to female teachers, but this difference was not very significant. However, it is important to further analyse the reasons of those who claimed the training was not very effective in order to be able to conduct more effective digital literacy training. Furthermore, aspects, such as materials, speakers, atmospheres, participants, and facilities should be considered wisely before conducting the training.

\section{Acknowledgements}

The authors would like to express their gratitude to the Directorate General of Higher Education, Research and Technology of the Ministry of Education, Culture, Research, and Technology, who has provided research grants through the Stimulus Community Service scheme. Then our gratitude also goes to the Headmaster and teachers at SMAN 1 Bandar Baru as research participant of this study. After that, we would like to thank the Head of LPPM Universitas Serambi Mekkah and research assistant who assisted authors in completing this study. Every author has contributed in writing this article proportionally. 


\section{References}

Gebhardt, E., Thomson, S., Ainley, J., \& Hillman, K. (2019). Teacher gender and ICT. In Gender Differences in Computer and Information Literacy (pp. 53-68). Springer, Cham.

Ghavifekr, S., \& Rosdy, W. A. W. (2015). Teaching and learning with technology: Effectiveness of ICT integration in schools. International Journal of Research in Education and Science, 1(2), 175-191.

Islahi, F. (2019). Exploring teacher attitude towards information technology with a gender perspective. Contemporary educational technology, 10(1), 37-54.

Kementrian Pendidikan dan Kebudayaan (2017). Panduan gerakan literasi nasional. Retrieved on November 2021 from https:/gln.kemdikbud.go.id/glnsite/wpcontent/uploads/2017/08/panduan-gln.pdf

Makworo, E. O., Nyakoe, G. M., \& Abuya, T. K. (2021). Gender and teacher attitude toward digital literacy programme in Kisii county primary schools. International Journal of Research in Business and Social Science, 10(4), 383-390.

Manyilizu, M., \& Gilbert, M. G. (2015). The use of ICT between male and female teachers in secondary schools in Tanzania: A case of Dodoma municipality.International Journal of Education and Research, 3(12), 417-428.

Markauskaite, L. (2006). Gender issues in preservice teachers' training: ICT literacy and online learning. Australasian Journal of Educational Technology, 22(1), 1-20.

Mbugua, S. N., Mbugua, S. N., Kiboss, J., \& Tanui, E. (2015). Influence of integration of information communication technology in teaching on students' academic performance. Journal of Education and Practice, 6(24), 7-13.

Ravinath, J. M. A. N. R. (2019). Teaching and Learning with Technology: Effectiveness of ICT Integration in Higher Education (Doctoral dissertation, Faculty of commerce \& Management).

Shapka, J. D., \& Ferrari, M. (2003). Computer-related attitudes and actions of teacher candidates. Computers in Human Behavior, 19(3), 319-334.

Soroya, S. H., \& Ameen, K. (2020). Subject-Based reading behaviour differences of young adults under emerging digital paradigm. Libri, 70(2), 169-179. 